\title{
THEORETICAL BASES OF FORMATION AND DEVELOPMENT \\ OF AGRICULTURAL ORGANIC PRODUCTION IN UKRAINE IN MODERN ECONOMIC CONDITIONS
}

\author{
Dmytro Fedchyshyn ${ }^{1}$ \\ *Corresponding author E-mail: marlynkh@gmail.com
}

\begin{abstract}
A R T I C LE IN F O
Review Article

Received: 31 March 2020

Accepted: 05 August 2020

doi:10.5937/ekoPolj2003939F

UDC 631.147:339.18(477)

Keywords:

Ukraine, organic products, agricultural sector, agricultural land, agriculture
\end{abstract}

JEL: P48, P14, D86

\begin{abstract}
A B S T R A C T
The article discusses the current state of the global market for organic products and the main trends of organic production in Ukraine. The analysis of the main indicators of the leading countries in the production and sale of organic products is carried out. Based on a comparison of the indicators of the Ukrainian market for organic products with world leaders, it was concluded that the Ukrainian market for organic products needs: the formation and implementation of a national management model, improving legislation and the structure of certification organizations, drawing up a program of financial, information and marketing support for domestic producers.
\end{abstract}

(C) 2020 EA. All rights reserved.

\section{Introduction}

In modern economic conditions, the effective management of agricultural production depends on the degree of its balance and applied organizational and economic methods. The main goal of organic farming is to produce high quality food in precisely defined conditions (Stojic, Dimitrijevic, 2020). Public awareness has reached such a level of development when an increase in the volume of production is not the only criterion for the activity of agricultural production. The preservation of natural resources becomes more and more important. This is due to the constantly increasing anthropogenic pressures on the environment - soil cover, biological organisms, atmosphere and water resources, due to what there is the violation of natural balance.

The formed dilemma of the further development of agricultural production and the preservation of the natural environment as the basis for the life of future generations predetermined the search for alternative options for the development of the industry. Over the past three decades, leading foreign scientists and agricultural practitioners, in order to solve territorial environmental problems and improve food quality, have gradually switched to organic farming methods, turning this area of production into

1 Dmytro Fedchyshyn, Ph.D, senior researcher, Zaporizhzhia National University, Zaporizhzhia, Ukraine, Phone: +38 0936466 075, E-mail: marlynkh@gmail.com, ORCID ID (https://orcid.org/0000-0002-1565-8150) 
a strategically important and significant sector of the economy. The most obvious advantage of the organic farming, among many benefits, over the other agricultural production methods is usage of environmentally sustainable systems in crop and livestock production (Čagalj, Grgić, Gugić, 2020). Organic farming represents a comprehensive system of farm management and food production that protects environment, preserves biodiversity and natural resources. The sustainability of organic production is reflected in the rational use of natural resources, without exhausting, but rather through maintaining and increasing their diversity, leaving no negative impacts on the environment (Roljević Nikolić, Vuković, Grujić, 2017).

In particular, the agrarian sector of the Ukrainian economy greatly influences the formation of gross domestic product, thereby ensuring the country's food security. One of the strategic tasks of the state during the formation of food security is the greening of agricultural production, an important place in which is given to increasing the volume of organic production.

Ukraine has everything necessary for the formation of agriculture, focused on the production of organic products: long-term agricultural traditions, vast areas of agricultural land, as well as an insignificant level of intensification and chemicalization of the agricultural sector in comparison with industrialized countries. Taking into account the considerable resource potential of the country in the agricultural sector, it is of great importance to provide a mechanism that would contribute to the development of organic agricultural production in Ukraine and increase on the basis of this competitiveness of the national economy.

\section{Materials and methods}

The theoretical and methodological basis of the study is the dialectical method of cognition, a systematic approach to the study of economic phenomena and processes, scientific works of domestic and foreign scientists on the problems of theory and practice of ensuring the development of organic production. Special research methods are also used, in particular: abstract-logical - to generalize the components of the mechanism for ensuring the development of organic production, formulating conclusions; economic and statistical - while analyzing the current state and predicting the prospects for the development of organic production in Ukraine and the world; graphic - when constructing graphic images of the processes under study.

\section{Results and discussions}

\section{Ecological and economic essence of agriculture focused on the production of organic products}

The feasibility of forming the theoretical foundations of economic relations that are determined in the process of interaction between human society and the natural environment, as well as the need to develop methods for regulating the rational use of natural resources, predetermined the emergence of a new scientific direction - 
environmental economics, which arose on the basic principles of the scientific theory of welfare and neoclassical economic theory.

The regulatory framework of environmental economics is the theory of external effects of economic production, which have a positive or negative effect on the opposite side. The theory of external effects is based on the fact that environmental pollution causes economic damage, and this damage can be materially estimated and, if necessary, monetary compensated. The English economist A. Pigou was one of the first to study the costs associated with external effects. The scientist proved that environmental pollution leads to an increase in external costs. At the same time, the main goal of any organization is to minimize production costs in order to increase profits, as a result - the desire to reduce environmental costs. In this case, environmental pollution is not considered as production costs and, accordingly, the cost of eliminating pollution is not included in the cost of production. With this approach, society, individual organizations, citizens will be forced to spend their additional material and financial resources on the elimination of environmental damage. Consequently, the total social costs and production costs will be formed from individual and external costs, expressed in monetary value (Pigou, 1924).

The representative of the neoinstitutional orientation in economic theory, R. Coase, believes that the root cause of external effects is the lack of clearly established ownership rights to natural resources and environmental objects. The author believed that if this shortcoming is eliminated, then optimality in the quality of the environment can be ensured in market conditions. In this case, the role of the state will be to establish such ownership rights (Coase, 1990).

Nevertheless, in spite of the achievements of scientists in the field of the theory of external effects, the main problems of taking into account external effects in the formation of the economic mechanism of environmental management have not yet been widely reflected in scientific research.

The further formation and development of social production dictates the need to take into account environmental factors and principles. It requires the search for new directions in the field of environmental management, based on maintaining the basic conditions that are important for human life and social production - clean air, water and soil resources, and neutralizing the possibility of depleting these resources. Objectively, there is a need of development of the concept of ecological-economic balance. Thus, the problems closest to those identified were those contained in the Concept of Sustainable Development of the World Community, presented at the United Nations conference in the early 90s, which was formed as an alternative to the prevailing stereotype of "consumer society" and the main economic development paradigms. 
It is believed that the concept of "sustainable development" was first mentioned in 1987 at an annual report presented by the World Commission on Environmental Protection, as "a development process in which existing social needs are met without the risk of likely harm to the process of satisfying the needs of future generations" (United Nations, 1992).

As theoretical studies show, the problems of sustainable development are often associated only with the state of the natural environment, not taking into account or underestimating the equally significant factors associated with sustainable development - political, social, economic, cultural, national-ethnic, etc. In the modern scientific environment, there is a position that is based on the principles of sustainable development. It is associated with the need to move from the consideration of the economic system in its pure form to the analysis of ecological and economic systems. Theoretical and methodological foundations of the sustainability of agricultural production in the ecological and economic aspectare investigated in the works of many economists. For example, A. Zhuchenko believes that a unilateral, mainly technogenic and chemical strategy for intensifying agricultural production, based on the application of ever-increasing costs of irreplaceable energy resources, has shown its failure to ensure sustainable, resource-energy-efficient and environmental development of agricultural production. As a result, the author proposed the use of a strategy of adaptive intensification, focused on the integrated use of chemical, technological and biological factors in order to increase the efficiency of agricultural production. This strategy includes: 1) elimination of environmental pollution and destruction when chemical fertilizers, plant protection products are applied, and gentle soil treatment is used; 2) bio-greening of technological processes of intensification; 3) reduction of energy costs; 4) production of quality and safe food and industrial raw materials (Zhuchenko, 1994).

In partnership with other United Nations Member States, Ukraine has undertaken the obligation to adapt and implement the global goals and objectives of the "Sustainable Development Goals", which were approved at the United Nations Summit on Sustainable Development (United Nations, 2015), taking into account national economic, environmental, social, legal and other specifics of the strategy of balanced (sustainable) development of Ukraine until 2030. In this regard, the President of Ukraine issued a Decree "On Sustainable Development Goals of Ukraine until 2030" of September 30, 2019 (President of Ukraine, 2019), which names the goals and outlines tasks for organic production through the prism of solving problems to overcome poverty, prevent hunger, ecology, nature management, environmental protection, use of land and other natural resources in agriculture, investment attraction, etc.

It is rightly emphasized in the legal literature on the strategic importance of cooperation between Ukraine and the European Union in such areas of cooperation as promoting modern and sustainable agricultural production, taking into account the need to protect the environment, in particular, disseminating the use of organic production methods and the use of biotechnology through the introduction of best practices in these areas (Urkevych, 2015). 
Based on foreign experience in organic agricultural production, some Ukrainian organizations in the agricultural sector are starting to turn agricultural production to alternative and innovative methods. The land use of these organizations is based on the use of an ecological fertilizer system that allows the use of organic and green fertilizers instead of chemical natural ones. Agrotechnical soil cultivation in this management system is considered as energy-saving. It is based on the combination of plowing and surface soil cultivation in accordance with the requirements of the climatic and territorial landscape conditions of the area, as well as the use of combined units. Over the past two decades, Ukrainian agriculture has been trying to introduce organic farming methods into agricultural production and creating specialized companies for the cultivation and processing of organic agricultural products in various regions of Ukraine.

It should be noted that a significant share of these companies was formed with the financing and support of a number of European countries - Germany, Switzerland, Denmark. For example, a foreign investor is IFC, which provided \$95 million to agro holding "Kernel" for working capital replenishment (Fedchyshyn, Ignatenko, Shvydka, 2019).

Most of the products manufactured by these enterprises are supplied to the ecological markets of European countries, which make producers of ecologically clean products dependent on market conditions, hampering their orientation on the domestic market of ecological products.

Ukrainian land has always aroused interest from foreign investors as a means of production and an object of investment. The tendency to increase such interest has not changed for a long time, and in the near future there are no preconditions for reducing the interest of the land. Taking into account the fundamental importance of the land as a strategic asset for any country, the regulation of property relations and land use occupies a special place in all developed legal systems (Fedchyshyn, Ignatenko, Bondar, 2019).

It should be noted that according to the study "The world of agriculture. Statistics and emerging trends", conducted in 2017 by IFOAM and the Research Institute of Organic Agriculture (German: Forschungsinstitut für biologischen Landbau - FiBL), there were 181 countries engaged in organic farming (table 1) (Wilier, Lernoud, 2019).

Table 1. Organic agriculture: key indicators and leading countries

\begin{tabular}{|c|c|c|}
\hline Indicator & Quantity & Leading countries \\
\hline $\begin{array}{c}\text { Organic producers } \\
\text { (countries) }\end{array}$ & 181 countries & $\begin{array}{c}\text { New countries (2019): Brunei, Cape Verde, Hong } \\
\text { Kong, Monaco, Sierra Leone }\end{array}$ \\
\hline Organic agricultural land & 69.8 million ha & $\begin{array}{c}\text { Australia (35.6 million ha), Argentina (3.4 million } \\
\text { ha), China (3 million ha) }\end{array}$ \\
\hline Organic producers & 2.9 million & India (835000), Uganda (210352), Mexico (210000) \\
\hline Organic market & 90 billion euro & $\begin{array}{c}\text { USA (40 billion euro), Germany (10 billion euro), } \\
\text { France (7.9 billion euro) }\end{array}$ \\
\hline $\begin{array}{c}\text { Consumption of organic } \\
\text { products per capita }\end{array}$ & 10.8 euro & $\begin{array}{c}\text { Switzerland (288 euro), Denmark (278 euro), } \\
\text { Sweden (237 euro) }\end{array}$ \\
\hline
\end{tabular}

Source: FiBL survey 2019, based on national data sources and data from certifiers (Wilier, Lernoud, 2019) 
In 2017, there were 2.9 million organic producers in the world, compared to 200 thousand in 1999. Moreover, 69.8 million hectares of certified agricultural land were allocated for organic farming (11 million hectares in 1999). There are only 93 countries in the world where the production and marketing of organic products is legislatively fixed and regulated by legal acts. In other countries, due to the lack of a legislative framework for regulating issues in the organic agriculture industry, the production of organic products is limited to the choice of the manufacturer who refused to use mineral fertilizers and plant protection products.

The global market of organic products in 2017 amounted 90 billion euro. Moreover, an increase in the market can be traced every year, starting in 1999. The country with the largest market for organic products is the United States (40 billion euro), followed by Germany with a market size of 10 billion euro. The third and fourth places are occupied by France and China ( 7.9 billion euro and 7.6 billion euro, respectively) (figure 1) (Wilier, Lernoud, 2019).

Figure 1. Countries with significant organic market volumes

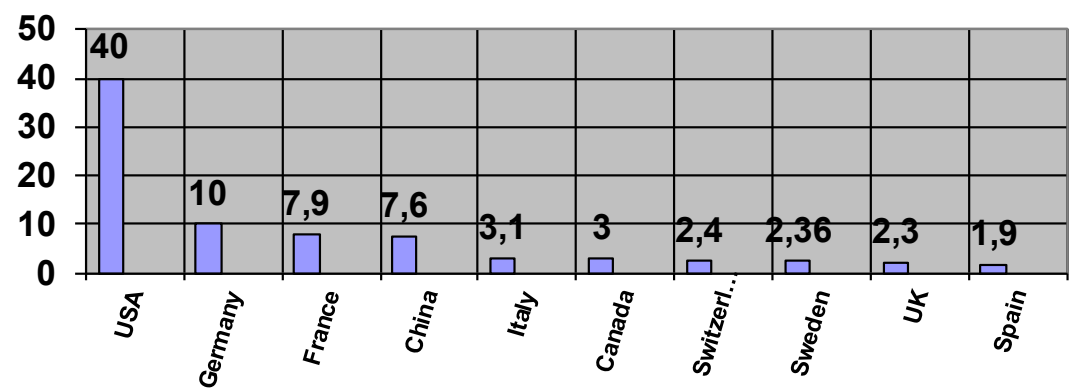

Source: FiBL survey 2019, based on national data sources and data from certifiers (Wilier, Lernoud, 2019)

Organic distribution channels in the world vary from country to country. In the past, the countries involved in the retail trade, showed a steady growth in their volumes of organic markets. As an example of such countries we can name Austria, Denmark, Switzerland, United Kingdom (table 2) (Wilier, Lernoud, 2019).

Table 2. Sales of organic products through various sales channels in Western European countries, million euros

\begin{tabular}{|c|c|c|c|c|}
\hline Country & General retailers & Specialized retailers & Direct sales & Other channels \\
\hline Austria & 1398 & 325 & - & - \\
\hline Belgium & 354 & 177 & 38 & 63 \\
\hline Denmark & 1520 & 81 & - & - \\
\hline France & 3652 & 2874 & 1006 & 390 \\
\hline Germany & 5930 & 2910 & - & 1200 \\
\hline Italy & 1595 & 865 & - & 677 \\
\hline Switzerland & 1979 & 247 & 130 & 80 \\
\hline United Kingdom & 1677 & 405 & - & 322 \\
\hline
\end{tabular}

Source: FiBL-AMI survey 2019, based on national data sources (Wilier, Lernoud, 2019) 
However, the financial crisis has shown that dependence on supermarkets is dangerous. Supermarkets, in turn, consolidated their position as a driving force in the market, so specialized sales channels are faced with huge competition.

It should be noted that there is a gradual increase in demand for organic agricultural products and in the domestic market of Ukraine. One of the most important channels of distribution and promotion of organic products in Ukraine are small specialized health food stores in major cities (for example, organic shops "Натур Бутик", organic grocery store network "Eco-Chic", etc.). Supermarkets are the most powerful organic distribution channel in Ukraine (Bezus, 2011). Supermarket "Good Wine" sells domestic and imported organic production, combining it in the "Good Food" section. Supermarket "Megamarket" represented to consumers separate sections with organic products. Certified organic products are also presented in supermarkets "Auchan", "Delight", "Billa", "Furshet", "Novus", etc., with special attention on organic dairy and meat products, cereals, flour, bakery products, jams, juices, eggs, honey, teas, vegetables, fruits, etc. (Boyko, 2011). Consumer demand and the emergence of organic agricultural products in supermarkets have led to a significant increase in sales, even though its share is less than $1 \%$ on store shelves (Kostin, 2011).

There are different views on the demand for these agricultural products: some experts claim that a segment of consumers, which are ready to pay a higher price for ecologically clean agricultural food (especially in large cities), has already emerged in the country, while others believe that such products have not yet been consumed. However, as we can see, there is a trend of increasing demand in the organic agricultural market in the world and increased interest on the part of business entities. Therefore, it can be argued that production of such products has increased (Chernishov, Levchenko, Mazurkevich, 2016).

At present, there are 69.8 million hectares of organic land worldwide. Only lands that have undergone a transitional period are considered. The region with the largest area of organic land is Oceania, with 35.9 million hectares certified for organic farming. This is followed by Europe with an area of 14.6 million hectares, Latin America - 8 million hectares, Asia - about 6.1 million hectares, North America - about 3.2 million hectares and Africa - 2.1 million hectares (figure 2) (Wilier, Lernoud, 2019).

Figure 2. Distribution of organic lands by regions of the world
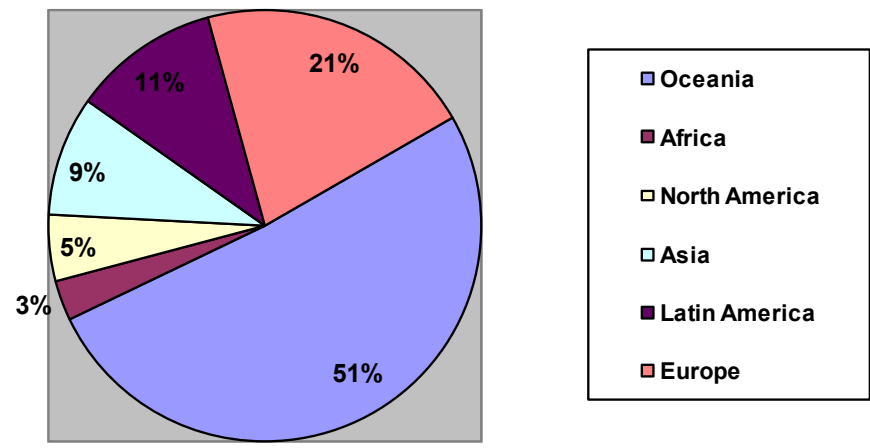

Source: FiBL survey 2019 (Wilier, Lernoud, 2019) 
In Oceania, more than a half (51\%) of the world's organic land is concentrated. Europe is a region that has shown fairly solid organic land growth over the past few years. The largest share belongs to countries such as: Spain (2.1 million hectares), Italy (1.9 million hectares), France (1.7 million hectares). In this rating, Ukraine occupies the 20th place with an area of organic land of 411.2 thousand hectares (Lialina, MatviienkoBiliaieva, 2019). Europe accounts for $21 \%$ of the world's organic land, followed by Latin America (11\%).

The increase in the total area of agricultural organic land is due to the transformation of existing arable land and gardens in accordance with the standards of organic agriculture, as well as through the development of new territories. For example, in Europe, out of 12.7 million hectares of organic land, 8 million have already passed transitional period, and the others are in the transition to organic production. This trend indicates that in the near future we can expect an increase in the supply of organic products on the market.

On average, the area of agricultural land per capita in Europe is 0.43 hectares, in Ukraine -0.90 hectares, arable land -0.24 and 0.67 hectares respectively. The share of certified organic land in the total agricultural area of Ukraine is almost $0.7 \%$ (Cabinet of Ministers of Ukraine, 2017). Ukraine ranks first in the Eastern European region in terms of certified organic arable land, specializing mainly in the production of cereals, legumes and oilseeds (Chernishov, Levchenko, Mazurkevich, 2016).

It should be emphasized that Ukraine has all the necessary conditions for the production of organic products and their further development, which is able to meet not only domestic demand, but also to occupy a niche in the world market. Some steps have already been taken in this direction. The total area of agricultural land in Ukraine occupied by organic production in 2017 was 420 thousand hectares, which is 2.5 times higher than the corresponding figure of 2002 (International Federation of Organic Agriculture Movements, 2019).

According to official IFOAM data, the number of farms engaged in organic farming in Ukraine is increasing year by year. If in 2002 there were 31 such enterprises, then in 2017 there were 375 organic farms. As a result, there is an increase in organic production in the domestic market, increasing interest from the processing industry (International Federation of Organic Agriculture Movements, 2019). If the general tendency of development of organic agro-production in Ukraine is maintained, in 2020 the area of organic crops can increase to 507 thousand hectares, and the number of certified organic farms will increase to 575.

However, a considerable part of organic agricultural production (about 80\%) is exported abroad due to the lack of development of domestic markets. The main export market for Ukrainian organic products is the European Union. The Netherlands, Germany, Switzerland, the Czech Republic, Poland, Italy, Greece, Moldova and Norway are the main countries to which organic products are exported from Ukraine. Middle Eastern countries, such as the United Arab Emirates, are beginning to become interested in Ukrainian certified organic products. 
The development of organic agriculture strongly depends on economic factors, mainly including demand, prices of organic products and the level of producers' support (BaerNawrocka, Blocisz, 2018).

The practice of farming, focused on the production of organic products, proves that organic farmers do not earn more income due to their higher production costs including labor, insurance and marketing charges (Uematsu, Mishra, 2012). Profitability of organic farms is very dependent on higher prices of production (Krause, Machek, 2018). According to Nieberg's and Offermann's research, it was easier for the organic farms to achieve higher prices for the crop production, but more difficult for the livestock production (Nieberg, Offermann, 2003). So, consumers' preferences are the fundamental factor in the success of the market for organic products. Numerous studies have found that health benefits are the main motives for buying organic food products (Wier, Calverly, 2002; Roitner-Schobesberger et al., 2008). The importance of health and environmental concerns reflects the growing affluence of consumers (Ham, 2019).

For example, according to the research conducted in Croatia (Čagalj, Haas, Morawetz, 2016), consumers are ready to spend more for fruit and vegetables from organic production (apples, tomatoes), if there is proof of organic production and because of the belief in health benefits of organic food. The same support we get from the research results conducted in Sweden (Bosona, Gebresenbet, 2018).

Consumers mostly describe organic food as food that is ecologically acceptable, has a positive effect on health and has good sensory quality, while the main disadvantages are high price and insufficient representation on the market (Gajdić, Petljak, Mesić, 2018).

So, foreign markets of ecological food are mainly targeted at consumers who are able and willing to buy a quality product at a higher cost. In Ukraine a class of wealthy people has also formed, but it will be wrong to orient the organic food market only to wealthy people.

We believe that Ukrainian agricultural producers of organic products need an appropriate segment of the food market, aimed at consumers who care about maintaining their health and the health of their loved ones. Consumers of organic products can be children (baby and diet food); people with poor health; patients undergoing rehabilitation, spa treatment; people with food allergies; agritourists and other organic products.

The importance should be given to scientific research in the direction of forming a strategy for the transition of a particular segment of agricultural producers to the organic way of farming.

\section{Methodological aspects of the formation of the concept of agricultural development, focused on the production of organic products}

When forming a methodological approach to the development of the system of land relations in the direction of agricultural production of organic products, there is a real opportunity to introduce important adjustments to land relations at the local level. This is due to the unevenness of the factors of natural and economic environment. In addition 
to the political orientation of the authorities, there are still quite objective reasons that have a serious impact on the level of development of land relations at the local level. A modern feature of agricultural lands is not only a general decrease in their area, but also deterioration in the quality of their land, and a decrease in the soil-biological and economic fertility of the land.

In addition, today, a number of reasons can be identified that slow down the development of organic agricultural production in Ukraine: 1) difficulties with investing in projects for the development of production and processing of organic products; 2) lack of a market for organic products; 3 ) lack of qualified specialists in the field of greening land use and certification of organic products.

The current situation in the agricultural sector of Ukraine does not imply a quick and widespread rehabilitation of it. As a result, it is required at the state level to define clear strategic and tactical goals for the systematic development of agriculture oriented towards the organic production. It is necessary to justify specific ways to achieve these targets, clearly define measures of state support, and outline the sequence of stages of reforming the system of land relations with organic development guidelines.

It seems that the awareness of the importance and need for a gradual transfer of the agricultural land use system from traditionally developed to organic will give a new impetus to the development of the entire agricultural sector. A systematic analysis and assessment of the possibility of using the world experience in organic farming in conjunction with the established traditions of land use are a prerequisite for the strategic development and strengthening of the position of agriculture in the system of the national economy.

It should also be noted that due to the increasing growth in the consumption of organic products in the economically developed countries of the European Union, North America and Asian countries, and also taking into account the limited land resources suitable for the purpose of maintaining an organic land use system in these countries, it can be assumed that in subsequent years, developing countries will be able to take a leading place in the global production and export of organic food. Ukraine, with its significant potential in increasing the land area suitable for the production of organic products, the availability of labor resources in rural areas, can occupy its niche in the global organic food markets.

In this regard, it is necessary to make timely and comprehensive decisions in determining the nomenclature of organic products, the formation of mechanisms of state support for agriculture, focused on the production of organic products and the promotion of organic products on domestic and foreign markets.

The development of agriculture in Ukraine, focused on the production of organic products should be based on solving a list of interrelated priorities:

- conducting land monitoring in order to determine the land potential suitable for the production of organic products; 
- justification of methodological foundations for the development of a mechanism for the formation and development of agriculture, focused on the production of organic products;

- development and co-financing of programs aimed at the conservation and restoration of soil fertility of agricultural lands;

- implementation of programs aimed at improving knowledge and developing skills in maintaining organic land use systems for agricultural producers of various organizational and legal forms of ownership in order to overcome the deficit of economic thinking and to establish an adequate level of education;

- development of national standards for certification of agricultural organic products, as well as the creation of conditions for organic products to pass international environmental certification.

The fundamental objective of the organic land use system is the development of incentives for the production and sale of organic food. The emerging system of organic farming should include the following activities:

- development and adoption of the regulatory framework necessary for the effective functioning of the system of organic agricultural production and markets for organic products;

- $\quad$ introduction of the necessary amendments to the current tax legislation aimed at supporting and economic stimulation of the developing organic sector of agricultural production;

- development of a set of measures and the adoption of a state program to support agricultural producers of organic products;

- providing consulting and information support to organic producers and the formation of an environmental culture of consumers;

- $\quad$ organization of an environmental management system in national agricultural production;

- organization of a centralized marketing service promoting the organic production of Ukrainian agricultural producers in domestic and international markets.

The main condition for the effective functioning of the proposed system is the development of an economic mechanism for organizing agricultural production of organic products both in large agricultural organizations and in small organizational and legal forms of management.

Today, there are many parties willing to engage in organic production in Ukraine and invest in its development, but they need state support, especially during the conversion period. In Ukraine, there is no government strategy and program to support the 
development of organic farming, which hinders the formation of the organic agricultural market due to the uncertainty of investors, credit institutions, farmers themselves about the feasibility, effectiveness and absence of risks of such production. Therefore, first of all, it is necessary to introduce a state program for the development of production of organic agricultural products, which will anticipate the development of this sector of economy and create the necessary frameworks for the coordination and control of organic production, as well as contribute to the expansion of markets for organic products. The main financial and economic measures for implementing state support for the development of organic agricultural production in Ukraine should include: subsidizing interest rates on loans, subsidizing part of the costs of production and crop insurance for organic producers, preferential lending and taxation, as well as improving mechanisms for regulating regional markets.

Thus the production of organic agricultural products, as a promising form of economy in Ukraine, depends on the method and extent of government support. Such support for organic producers abroad has become an effective tool for stimulating the development of organic farming.

\section{Conclusions}

Having considered the major global trends in the development and management of organic production and considering Ukraine's accession to the World Trade Organization and the association with the European Union, we can conclude that the Ukrainian market for organic products runs the risk of facing the expansion of foreign producers, which operate in much more favorable financial and legal conditions. Thus, in order to ensure that the Ukrainian market for organic products does not die as soon as it starts functioning, it needs to form and implement a national management model that will take into account both the interests of developing the domestic market and the interests of exporting organic products. Improving the legislation and structure of certification and supervisory organizations, drawing up a program of financial, informational and marketing support for domestic producers of organic products are those measures without which the development of Ukrainian market for organic products in the face of fierce international competition is almost impossible.

\section{Conflict of interests}

The authors declare no conflict of interest.

\section{References}

1. Baer-Nawrocka, A., \& Blocisz, J. (2018). Efficiency of Polish organic and conventional farms. Studies in agricultural economics, 120, 55-60. doi: https://doi. org/10.7896/j.1724

2. Bezus, R. (2011). Ринок органічної продукції в Україні : проблеми та перспективи. Економіка АПК, 6, 47-52. [In English: Bezus, R. (2011). Organic market in Ukraine: problems and prospects. Economy of AIC, 6, 47-52]. 
3. Bosona, T., \& Gebresenbet, G. (2018). Swedish consumers' perception of food quality and sustainability in relation to organic food production. Foods, 7(4), 1-17. doi: https://doi.org/10.3390/foods7040054

4. Бойко, Л. (2011). Передумови розвитку органічного виробництва в Україні. Землевпорядний вісник, 2, 30-35. [In English: Boyko, L. (2011). Prerequisites for the development of organic production in Ukraine. Land management herald, 2, 30-35].

5. Кабінет Міністрів України (2017). Постанова “Деякі питання удосконалення управління в сфері використання та охорони земель сільськогосподарського призначення державної власності та розпорядження ними”. [In English: Cabinet of Ministers of Ukraine (2017). Resolution "Some issues on improving the management mechanism in the field of use and protection of agricultural land of state ownership and disposal of it”. № 413]. Retrieved from https://zakon.rada.gov. ua/laws/show/413-2017-\%D0\%BF\#n12 (January 25, 2020).

6. Čagalj, M., Grgić, I., \& Gugić, J. (2020). Study on consumer preferences towards organic food in the market of Split, Croatia. Economics of Agriculture, 67(1), 285 292. doi: https://doi.org/10.5937/ekoPolj2001285C

7. Čagalj, M., Haas, R., \& Morawetz, U.B. (2016). Effects of quality claims on willingness to pay for organic food: Evidence from experimental auctions in Croatia. British Food Journal, 118(9), 2218-223. doi: https://doi.org/10.1108/BFJ11-2015-0453

8. Чернишов, I., Левченко, М., \& Мазуркевич, I. (2016), Стан і потенціал розвитку органічного свинарства України. Вісник аграрної науки Причорномор'я, 2, 149-154. [In English: Chernishov, I., Levchenko, M., Mazurkevich, I. (2016). State and potential of development of the organic pig breeding of Ukraine. Bulletin of Agrarian Science of the Black Sea, 2, 149-154].

9. Coase, R.H. (1990). The firm, the market and the law. Chicago: University of Chicago press.

10. Fedchyshyn, D., Ignatenko, I., \& Bondar, O. (2019). Protecting the rights of foreigners to investment-attractive land plots in Ukraine. Juridical Tribune, 9(2), 317-329.

11. Fedchyshyn, D., Ignatenko, I., \& Shvydka, V. (2019). Economic and legal differences in patterns of land use in Ukraine. Amozonia Investiga, 8(18), 103-110.

12. Gajdić, D., Petljak, K., \& Mesić, Ž. (2018). An exploration of distribution channels: challenges and opportunities for organic food producers in Croatia. Economics of Agriculture, 65(4), 1461-1482. doi: https://doi.org/10.5937/ekoPolj1804461G

13. Ham, M. (2019). Beliefs about effects of organic products and their impact on intention to purchase organic food. Ekonomski vjesnik, 32(1), 69-80.

14. International Federation of Organic Agriculture Movements (2019). Principles of organic agriculture. Retrieved from https:/www.ifoam.bio/sites/default/files/poa english_web.pdf (January 25, 2020). 
15. Kostin, P. (2011). Проблемы развития «органического» земледелия в его культуре. Настоящий хозяин, 6, 26-30. [In English: Kostin, P. (2011). Problems of the development of "organic" farming in its culture. The real owner, 6, 26-30].

16. Krause, J., \& Machek, O. (2018). A comparative analysis of organic and conventional farmers in the Czech Republic. Agric. Econ., 64(1), 1-8. doi: https:// doi.org/10.17221/161/2016-AGRICECON

17. Ляліна, Н., \& Матвієнко-Біляєва, Г. (2019). Механізм забезпечення розвитку органічного аграрного виробництва в Україні. Agricultural and Resource Economics: International Scientific E-Journal, 5(2). 121-140. [In English: Lialina, N., Matviienko-Biliaieva, G. (2019). Mechanism for providing the development of organic agricultural production in Ukraine. Agricultural and Resource Economics: International Scientific E-Journal, 5(2), 121-140].

18. Nieberg, H., \& Offermann, F. (2003). The profitability of organic farming in Europe. Organic Agriculture: Sustainability, markets and policies. OECD Workshop on Organic Agriculture, Washington, D.S. (September 23-26, 2002).

19. Pigou, A. (1924). The Economics of Welfare. London: Macmillan and Co. 872.

20. Президент України (2019). Указ “Про Цілі сталого розвитку України на період до 2030 року”. [In English: President of Ukraine (2019). Decree “On Sustainable Development Goals of Ukraine until 2030” №722/2019]. Retrieved from https:// www.president.gov.ua/documents/7222019-29825 (January 25, 2020).

21. Roitner-Schobesberger, B., Darnhofer, I., Somsook, S., \& Vogl, C. R. (2008). Consumer perceptions of organic foods in Bangkok, Thailand. Food Policy, 33(2), 112- 121. doi: https://doi.org/10.1016/j.foodpol.2007.09.004

22. Roljević Nikolić, S., Vuković, P., \& Grujić, B. (2017). Measures to support the development of organic farming in the EU and Serbia. Economics of Agriculture, 64(1), 323-337. doi: https://doi.org/10.5937/ekoPolj1701323R

23. Stojic, V., \& Dimitrijevic, M. (2020). Consumers' intentions to use of organically produced food in the Sumadija region. Economics of Agriculture, 67(1), 253-267. doi: https://doi.org/10.5937/ekoPolj2001253S

24. Uematsu H., \& Mishra A.K. (2012). Organic farmers or conventional farmers: where's the money? Ecological Economics, 78, 55-62. doi: https://doi.org/10.1016/j. ecolecon.2012.03.013

25. United Nations (2015). "Transforming our world: the 2030 Agenda for Sustainable Development" (25 September 2015). Retrieved from https://www.un.org/ sustainabledevelopment/sustainable-development-goals/ (January 25, 2020).

26. United Nations (1992). Report of the United Nations Conference on Environment and Development (Rio de Janeiro, 3-14 June 1992), Retrieved from https://undocs. org/en/A/CONF.151/26/Rev.1 (January 25, 2020). 
27. Urkevych, V. (2015). Organic agricultural production: legal issues of development in the aspect of European integration of Ukraine. Modern tendencies and prospects of development of agrarian, land and ecological law: mater. All-Ukrainian scientific-practical conf. (Kyiv, May 22-23, 2015), Kyiv, 74-76.

28. Wier, M., \& Calverly, C. (2002). Market penetration for organic food products in Europe. British Food Journal, 10, 45-62.

29. Wilier, H., \& Lernoud, J. (2019). The world of organic agriculture. Statistics and Emerging Trends 2019. Research Institute of Organic Agriculture (FiBL), Frick, and IFOAM. Organics International, Bonn. Retrieved from https://shop.fibl.org/ CHen/mwdownloads/download/link/id/1202/?ref=1 (January 25, 2020).

30. Жученко, А. (1994). Стратегия адаптивной интенсификаиии сельского хозяйства: кониепция. Пущино. [In English: Zhuchenko, A. (1994). The strategy of adaptive intensification of agriculture: concept. Pushchino]. 